\title{
Is Carbon Decoupling Likely to Happen in Africa: Evidence From Production and Consumption-based Carbon Emissions
}

Dagmawe Tenaw ( $\boldsymbol{\sigma}$ dagymanta@gmail.com )

\section{Research}

Keywords: Decoupling, production and consumption-based CO2emissions,Economic growth, Africa

Posted Date: June 16th, 2020

DOI: https://doi.org/10.21203/rs.3.rs-35687/v1

License: (c) (i) This work is licensed under a Creative Commons Attribution 4.0 International License.

Read Full License 


\title{
Is Carbon Decoupling likely to happen in Africa: Evidence from Production and Consumption-based Carbon Emissions
}

\section{Dagmawe Tenaw}

\author{
Department of Economics, Dire Dawa University, \\ Dire Dawa, Ethiopia \\ Email: dagymanta@gmail.com \\ ORCID ID: https://orcid.org/0000-0002-9768-0430
}

\begin{abstract}
Despite extensive studies made on decoupling between emissions and growth, evidences have shown no uniformity and vast majority of studies considered emissions generated at the point of production alone which do not explicitly account for emissions associated with international trade. Accordingly, this study examines the issue of decoupling between economic growth and carbon emissions in 25 African countries over 1990-2017, considering both production and consumption-based $\mathrm{CO}_{2}$ emissions. Different panel data estimation techniques which allow for cross-sectional dependence, heterogeneity, endogeneity and serial-correlation issues are applied for empirical analysis. The study results invariably indicate some evidence of relative decoupling for production-based emissions, but no robust evidence of decoupling for consumption-related emissions. Primary energy intensity and population are found as the main drivers of carbon emissions in Africa. Further, exports and imports have insignificant effects on territorial emissions, but significant and offsetting effects on consumption-based emissions. After all, this study suggests to incorporate emissions generated from consumption activities in emissions-growth linkage as production-related emissions alone would evidently be insufficient for decarbonizing economic growth.
\end{abstract}

Key words: Decoupling, production and consumption-based $\mathrm{CO}_{2}$ emissions, Economic growth, Africa 


\section{Introduction}

Rapid economic growth has been one of the most evident and notable features of African countries since the beginning of the new millennium, which has mainly been attributed to an improvement in the quality of public institutions, sustained high commodity prices, favorable conditions on global financial markets, opening the road to democratic frameworks and the creation of a more investment-friendly environment (Moro, 2016). According to UNCTAD (2020), Africa has been one of the fastest growing region and experienced average annual GDP growth rate of $4.2 \%$ for the period from 2000 and 2018. As reported in African Economic Outlook (2020), Africa's GDP growth is above the world average and the average for other emerging and developing economies (excluding China and India) in 2019 and six African countries are among the world's 10 fastest growing economies in the same year: Rwanda (8.7 percent), Ethiopia (7.4), Côte d'Ivoire (7.4), Ghana (7.1), Tanzania (6.8) and Benin (6.7).

The continued economic growth may, however, cause irreversible environmental risks as the growth process requires more quantities of energy inputs that increase the extraction and depletion of natural resources and the accumulation of wastes and pollutions emitted to the environment. Hence, achieving a transition towards greener growth and sustainable utilization of environmental resources need to be at the forefront of growth-oriented policies and strategies. In this regard, one of the prominent green growth concepts proposed as a way to achieve economic growth without or with less environmental hazards is the notion of decoupling ${ }^{1}$ : delinking (separating) economic growth from its adverse environmental impacts. The issue of whether growth can be decoupled from carbon emissions has become an important topic of many literatures in recent days.

This paper is motivated by different reasons. The first motivation for this study is that the vast majority of existing studies on decoupling relied on production-based emissions. These emissions, however, ignore the environmental impacts of consumption and of global trade. Put differently, emissions generated from domestic production provides incomplete picture of

\footnotetext{
${ }^{1}$ As noted in Nordic Council of Ministers (2006), the concept of decoupling is related to that of sustainability, but it could not be thought of as an approximation of sustainability. Decoupling is neither a sufficient nor necessary condition for sustainability. Decoupling indicators are not direct measures of sustainability, rather are reasonably good measures for progress towards sustainability.
} 
driving forces behind emission changes and are insufficient for climate change mitigation. Hence, considering consumption ${ }^{2}$-based emissions which measure emissions stemmed from domestic consumption and incorporate emissions embodied in international trade is quite worthwhile in this regard to enlighten the empirical fact in the decoupling analysis.

Second, although a large number of empirical studies have been undertaken on decoupling analysis, the findings have still shown no uniformity with respect to the possible channels, key drivers and extents (states) of decoupling between carbon emissions and economic growth. For instance, some recent studies (Mikayilov et al., 2018; Piłatowska and Włodarczyk, 2018; Schroder and Storm, 2018, among others) confirmed the existence of decoupling between carbon emissions and growth. While, some other studies like Hilmi et al. (2018) and Jiborn et al. (2018) found no evidence of decoupling. In such a controversial situation where the existing studies fail to come up with conclusive evidence, it is quite imperative to advance this line of research with further investigation of decoupling analysis.

Third, econometric models employed in some other empirical works of decoupling (Mir \& Storm, 2016; Hilmi et al., 2018; Schroder and Storm, 2018; Bhowmik, 2019, among others) are suffered from serious methodological problems such as unrealistic homogeneity assumption, problems arising from cross-sectional dependence, non-stationarity and endogeneity in data. Ignoring these issues, in fact if they exist, might lead to spurious, biased, inefficient, and inconsistent estimation results which in turn yield misleading conclusions and implications. The fourth motivation is that, as far as to the best of our knowledge, no prior empirical study on decoupling has been carried out in Africa as a region. Nevertheless, the region is structurally, historically, politically, and demographically different from other regions. Hence, one should expect that African countries will exhibit significance differences in their growth-environment linkage, and the lessons and observed facts from other regions may not hold in African economies.

Therefore, this study provides some empirical evidence from Africa using different panel data estimation techniques which address the above-mentioned methodological problems and

\footnotetext{
${ }^{2}$ Conceptually, PBA incorporates emissions embodied from exports, while CBA includes imported emissions. Hence,

$C B A=P B A-$ emissions from exports + emissions from imports
} 
contributes to the existing debate on decoupling of emissions from economic growth. To this end, we use both production-based and consumption-based carbon emissions data for 25 African countries over the period between 1990-2017. The study also assesses the role of international trade on emissions.

The rest of the paper is organized as follows: Section 2 provides a brief review of theoretical and empirical literatures on decoupling. Section 3 discusses data issues and methodology. Section 4 presents the empirical results and discussion and finally section 5 gives conclusion with some relevant policy implications.

\section{Brief Review of Literatures}

In exploring the relationship between carbon emissions and economic growth, the concept of decoupling has received global attentions as a significant indication of successful economyenvironment integration (Lin et al., 2015). Organization for Economic Cooperation and Development (OECD) has first started to discuss the notion of decoupling in early 2000s. As stated in OECD (2002), decoupling refers to a process of breaking the relationship between 'environmental bads' and 'economic goods.' It implies the possibility to reduce environmental impacts with little or no effect on economic growth. Decoupling is said to occur when the growth rate of GHG emissions are stable or less than growth rate of economic factors (e.g. GDP). In this regard, it is important to distinguish between the two basic types of decoupling: absolute and relative decoupling.

Absolute decoupling is a situation observed when environmental pressures (emissions) keep stable or decline as the economy grows (OECD, 2002; Ru et al., 2012; Mikayilov et al., 2018). It implies the reduction of emissions in absolute terms while keeping the pace of economic growth (the pressure of growth on environment is either stable or declining over time), which is a clear indication for greener economic growth path. On the other hand, relative decoupling involves a situation when emissions grow less rapidly (at a slower rate) than the pace of economic growth. That is, the growth rate of emissions remains positive, but less that the growth rate of GDP (OECD, 2002; Ru et al., 2012; Mikayilov et al., 2018; Piłatowska and Włodarczyk, 2018). 
Empirically, a large body of environmental and energy literatures have extensively examined the issue of decoupling between carbon emissions and economic growth, predominantly in relation to Environmental Kuznets Curve $\left(\mathrm{EKC}^{3}\right)$ hypothesis. In this regard, as noted in Mikayilov et al. (2018) and Piłatowska and Włodarczyk (2018), EKC hypothesis is expected to exist when relative decoupling turns into absolute beyond some turning point or, when emissions are absolutely decoupled from economic growth. Although a detailed review of literatures on decoupling analysis is beyond the scope of this study, a few general observations about some more recent empirical works made at different parts of the world are highlighted in table A1 (see appendix 1).

As can be seen from the table A1 in appendix 1, evidences are mixed and conflicting regarding the possible channels, key drivers, emission inventories and methodologies used and extents (state) of decoupling between emissions and economic growth over the periods considered. Further, most of the empirical studies on decoupling were conducted in developed and emerging economies. And, as far as we have reviewed, no prior decoupling study has been done so far in Africa as a region. Hence, it is quite interesting to further investigate the decoupling analysis in African context over recent years.

\section{Data and Methodology}

\subsection{Data Type and Sources}

This study used annual data set for 25 selected African countries ${ }^{4}$ spanning from 1990 to 2017. Production ${ }^{5}$-based $\mathrm{CO}_{2}$ emissions data are taken from Boden et al. (2017) and consumption ${ }^{6}$ -

\footnotetext{
${ }^{3} \mathrm{EKC}$ is a standard framework for describing an inverted-U shaped environment-growth relationship. It is a natural extension of decoupling analysis

${ }^{4}$ Benin, Botswana, Burkina Faso, Cameroon, Cote d'Ivoire, Egypt, Ethiopia, Ghana, Guinea, Kenya, Madagascar, Malawi, Mauritius, Morocco, Mozambique, Nigeria, Rwanda, Senegal, South Africa, Tanzania, Togo, Tunisia, Uganda, Zambia and Zimbabwe.

${ }^{5}$ Production-based emissions accounting (also called territorial-based) is a straightforward way of measuring emissions generated from the production of goods and services within the territory of a country. PBA is an accounting method that has being adopted under UNFCCC for international negotiations on climate mitigation

${ }^{6} \mathrm{CBA}$ (trade-adjusted) method has recently emerged as a prominent alternative approach, which accounts for emissions from domestic consumption of goods and services regardless of the place of production. This accounting method, unlike PBA, incorporates emissions embodied in international trade, which takes a significant share in global emissions. CBA assigns emission responsibility to the country where a product is finally consumed
} 
based $\mathrm{CO}_{2}$ emissions data are updated from Peters et al. (2011). The data for other variables were mainly obtained from World Development Indicators of World Bank. Further, the selection of sample countries was based on the availability of relevant data for the variables to be included in the study particularly on consumption-based $\mathrm{CO}_{2}$ emissions. Table 1 provides the summary statistics of the variables in the study across 25 selected African countries over 1990-2017.

\section{Table 1: Summary Statistics}

\begin{tabular}{ccccc}
\hline Variables & Mean & Std. dev. & Minimum & maximum \\
\hline Production-based $\mathrm{CO}_{2}$ emissions & $3.11 \mathrm{e}+07$ & $8.44 \mathrm{e}+07$ & 453878 & $4.97 \mathrm{e}+08$ \\
\hline Consumption-based $\mathrm{CO}_{2}$ emissions & $2.71 \mathrm{e}+07$ & $6.19 \mathrm{e}+07$ & 63141.26 & $3.61 \mathrm{e}+08$ \\
\hline GDP per capita, PPP & $3,770.307$ & $3,773.582$ & 361.091 & $20,319.49$ \\
\hline Population size & $2.66 \mathrm{e}+07$ & $3.06 \mathrm{e}+07$ & $1,058,775$ & $1.91 \mathrm{e}+08$ \\
\hline Primary Energy intensity & 9.396 & 7.028 & 2.462 & 50.135 \\
\hline Export share & 27.266 & 12.561 & 3.310 & 67.987 \\
\hline Import share & 35.311 & 12.888 & 5.734 & 84.763 \\
\hline
\end{tabular}

Note: the total number of observation for all variables is 700 .

\subsection{Model Specification: STRIPAT model}

Here, we start with Stochastic Impacts by Regression on Population, Affluence and Technology (STIRPAT) model to examine the notion of decoupling between carbon emissions and economic growth. STIRPAT model is a stochastic model derived from IPAT identity ${ }^{7}$ so as to empirically test hypotheses (York et al., 2003) and to analyze different proportional change of influences (Feng, 2017). The standard specification of STIRPAT model is:

$$
I=\alpha P^{\beta 1} A^{\beta 2} T^{\beta 3} e
$$

Where I represents environmental impact (e.g. carbon emissions), $\alpha$ is the constant term that scales the model, $\beta_{1}, \beta_{2}$, and $\beta_{3}$ are estimated coefficients of population (P), Affluence (A) and

irrespective of where along the global value chain emissions physically occurred (Baumert et al., 2019). According to recent studies, up to $25-30 \%$ of global emissions are generated from international trade (see Karakaya et al., 2018).

${ }^{7}$ IPAT identity is a widely applied mathematical framework in identifying the key drivers of environmental impact. It specifies environmental impacts as the multiplicative product of three key driving forces behind environmental change: population, affluence and technology. ( $\left.\mathrm{I}=\mathrm{P}^{*} \mathrm{~A}^{*} \mathrm{~T}\right)$. IPAT identity was introduced by Ehrlich and Holdren in 1971. Although IPAT identity is easy to manipulate and has clear and parsimonious specification, it does not allow for hypothesis testing and for non-proportional effects of the driving forces. To overcome these limitations, Dietz and Rosa (1994) extended IPAT identity in to a stochastic model called STIRPAT (see York et al, 2003; Feng, 2017). 
Technology (T) respectively and $e$ represents error term. For our analysis, the basic STIRPAT model stated in equation (1) can be re-expressed, after the inclusion of country-specific and time-specific effects and all variables are transformed in natural logarithm form, as:

$$
\ln I=\alpha_{i}+\delta_{t}+\beta_{1} \ln P_{i t}+\beta_{2} \ln A_{i t}+\beta_{3} \ln T_{i t}+\varepsilon_{i t}
$$

Since we use a panel data approach, countries are represented by the subscript, $i$ and time period are indexed by, $t$ and thus $\alpha_{i}$ and $\delta_{t}$ are the intercept parameters which vary across countries and years. In this study, we use production-based and consumption-based $\mathrm{CO}_{2}$ emissions as proxies for environmental impact. We also use GDP per capita as a measure of Affluence and total population size (POP) as a proxy for population effect. The technology variable is not a single factor, rather comprises many separate factors that influence environmental impacts and thus can be directly disaggregated by including additional factors in the STIRPAT model so long as they are conceptually consistent with the specification of the model (York et al., 2003). Accordingly, primary energy intensity (primary energy supply per unit of GDP measured at PPP) is used to represent the technology variable.

The standard STIRPAT model can be improved by including the quadratic term of Affluence (GDP per capita) to allow for curvilinear (non-monotonic) relationship between economic growth and emissions following the conventional EKC framework. We further extend the STRIPAT model by incorporating exports (Ex) and imports (Im) separately as a share of GDP in order to examine the impact of trade flows on $\mathrm{CO}_{2}$ emissions. Exports and imports are expected to have no significant effect on territorial emissions, whereas they are expected to have significant and offsetting(exports-negative and imports-positive) effect on consumption-related emissions. After all, the extended STRIPAT model can be formulated as follows:

$$
\begin{aligned}
\ln \mathrm{CO}_{2}=\alpha_{i}+\delta_{t}+ & \beta_{1} \ln P O P_{i t}+\beta_{2} \ln G D P_{i t}+\beta_{3}(\ln G D P)_{i t}^{2}+\beta_{4} \ln E I_{i t}+\beta_{5} \ln E x_{i t}+ \\
& \beta_{6} \ln \operatorname{Im}_{i t}+\varepsilon_{i t}
\end{aligned}
$$

\subsection{Econometric Model:}

In order to empirically examine the issue of decoupling between economic growth and carbon emissions and to assess the role of international trade on carbon emissions in African context, we employed different panel data estimation techniques. Accordingly, the extended STRIPAT 
model stated in equation (3) is estimated using Pesaran (2006) Common Correlated Effects Mean Group (CCE-MG) and Augmented Mean Group (AMG) estimator of Eberhardt and Teal (2010).

CCEMG and AMG estimators are heterogeneous panel data estimators that account for the issue of cross sectional dependence and endogeneity arises from the presence of common factors, robust to omitted variables, measurement errors, structural breaks, serial correlation and whether the variables are stationary or co-integrated or not (Eberhardt and Teal, 2011; Liddle, 2018). The CCEMG estimator is also robust to the presence of a limited number of "strong" factors like global shocks and an infinite number of "weak" factors such as local spillover effects (Eberhardt, 2012).

We consider the following empirical model, adopted from Eberhardt (2012):

$$
\begin{aligned}
& y_{i t}=\beta_{i} x_{i t}+u_{i t}, i=1,2, \ldots . . \mathrm{N} \text { and } \mathrm{t}=1,2, \ldots . \mathrm{T}
\end{aligned}
$$

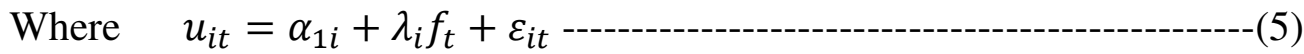

$$
\begin{aligned}
& x_{i t}=\alpha_{2 i}+\lambda_{i} f_{t}+\gamma_{i} g_{t}+e_{i t}
\end{aligned}
$$

From equation (4), $y_{i t}$ and $x_{i t}$ represent dependent variable and a set of regressors. $\beta_{i}$ is country-specific slope on regressor. Equation (5) contains three unobservables: group-fixed effects $\left(\alpha_{1 i}\right)$ which capture time-invariant heterogeneity across countries; $\lambda_{i} f_{t}-$ an unobserved time-variant common factor $\left(f_{t}\right)$ with heterogeneous country-specific factor loadings $\left(\lambda_{i}\right)$ captures time-variant

heterogeneity and cross-sectional dependence; and finally, $\varepsilon_{i t}$ is a white noise error term. Likewise, in equation (6), each regressor, $x_{i t}$ is displayed as a function of an individual fixedeffect term $\left(\alpha_{2 i}\right)$, time-variant heterogeneity $\left(f_{t}\right)$ and cross-sectional dependence $\left(g_{t}\right)$ with their respective factor loadings $\left(\lambda_{i}\right.$ and $\left.\gamma_{i}\right)$, and a white noise error term $\left(e_{i t}\right)$. The unobserved common factors $\left(f_{t}\right.$ and $\left.g_{t}\right)$ can be non-stationary and non-linear. Further, endogeneity may arise due to the presence of $f_{t}$ in both equations (5) and (6).

CCEMG estimator deals with cross-sectional dependence by augmenting cross sectional averages of the dependent and independent variables $\left(\bar{y}_{t}\right.$ and $\left.\bar{x}_{t}\right)$ as additional regressors in equation (4) and treated $f_{t}$ as nuisance. In contrast, $\mathrm{AMG}^{\mathbf{8}}$ estimator addresses cross-sectional

\footnotetext{
${ }^{8}$ As noted in Eberhardt (2012), the AMG estimator is implemented in three steps: first, a pooled regression augmented with time dummies is estimated by first difference OLS. The coefficients on the (differenced) time
} 
dependence by including a "common dynamic process" in the country regression (includes $f_{t}$ in the regression as a variable of interest) (Eberhardt, 2012).

For the sake of ensuring the robustness of our regression results, we also employed and panel Dynamic OLS (DOLS) estimators. DOLS is an OLS-based estimation technique in the presence of panel cointegration which help us to estimate the long run relationships. This estimator addresses heterogeneity issues by including individual specific intercepts into regression and by allowing serial-correlation properties of the errors to vary across panel members. It also accounts for potential endogeneity among variables in the model by augmenting the cointegrating regression with lead and lagged differences of the regressors to suppress the endogenous feedback effect. Further, the DOLS estimator provides reliable results for the cointegration relationship exists among non-stationary variables and produce asymptotically unbiased and normally distributed estimators (Hossfeld, 2010; Farhani et al., 2014; Mitic et al., 2017).

\section{Results and Discussion}

\section{1. $\mathrm{CO}_{2}$ emissions and GDP per capita}

Figure 1 illustrates the trend and comparison of production-based and consumption-based $\mathrm{CO}_{2}$ emissions and GDP per capita in average terms for 25 selected African countries over the period between 1990-2017. Accordingly, both territorial and consumption based emissions per person have grown in our sample countries over the last three decades with average annual growth of $1.17 \%$ and $1.29 \%$ respectively. GDP per capita has also increased with an average growth rate of $1.98 \%$ over the period considered.

Figure 1: Per capita $\mathrm{CO}_{2}$ emissions and GDP per capita, PPP $(1990=100)$

dummies are estimated cross-group averages of the evolution of the unobserved effect over time (the so-called 'common dynamic process'). Then, the country-specific regression model is augmented with the estimated common dynamic process as an explicit regressor.. Finally, the average of the country-specific parameters is estimated across panel members. 


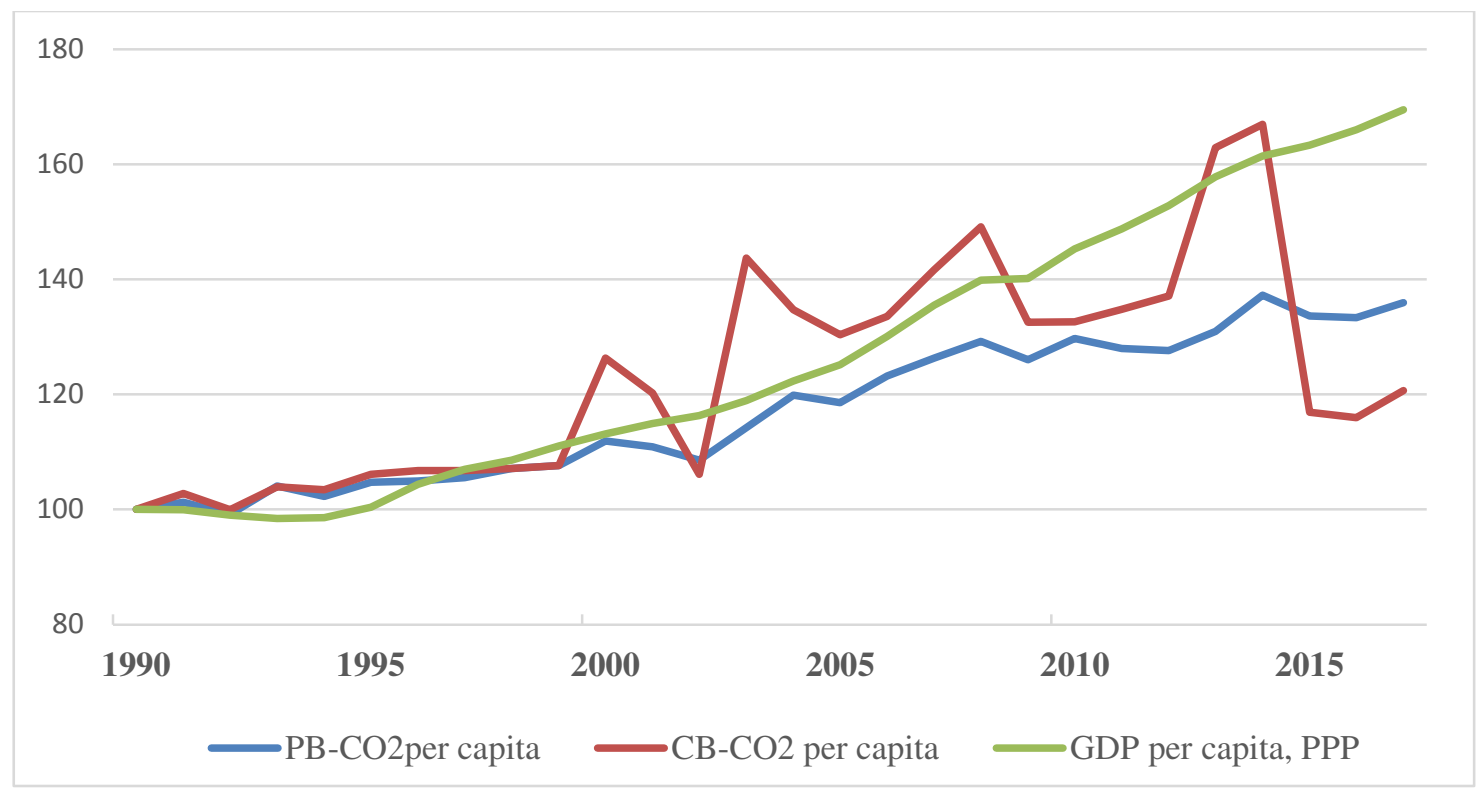

Figure 1 further depicts that the selected African countries had been net importers of carbon emissions until 2015 as their per capita consumption emissions outstrip territorial emissions per person. However, territorial emissions began to surpass trade-adjusted emissions since 2015. Note that there are differences at individual country level, with some selected countries being net-exporters, and some other countries being net importers of carbon emissions (see appendix 2).

\subsection{Decoupling Analysis: OECD Decoupling Method}

Different analytical methods of decoupling have been proposed in order to examine the occurrence of decoupling between economic growth and carbon emissions particularly since early 2000s. The OECD (2002) decoupling method is one of the most widely method and measures decoupling in terms of income elasticity of emissions and classifies the decoupling concept in to relative and absolute decoupling. It is helpful to provide quick and simple analysis on decoupling. OECD decoupling ratio 9 can be computed as the ratio of percentage change in environmental pressures (e.g. carbon emissions) to the percentage change in economic factors (such as GDP per capita). Here, OECD decoupling indicator is found once we subtract decoupling ratio from 1: (OECD decoupling indicator $=1-O E C D$ decoupling ratio).

\footnotetext{
${ }^{9}$ Mathematically, decoupling ratio $=\frac{\% \Delta E P}{\% \Delta D F}=\frac{(E P / D F)_{t 1}}{(E P / D F)_{t 0}}$, where EP and DF represent environmental pressures and economic factors (driving forces) respectively. subscript of $t 1$ and $t 0$ denote beginning and end year in the study (see Ru et al., 2012; Lin et al., 2015).
} 
Decoupling occurs during a period when the decoupling indicator is greater than zero. In this regard, the decoupling is relative if the decoupling indicator $>0$ and $\% \Delta \mathrm{EP}>0, \% \Delta \mathrm{DF}>0$ and absolute decoupling occurs when the decoupling indicator $>1$ and $\% \Delta \mathrm{EP} \leq 0, \% \Delta \mathrm{DF}>0$. If decoupling indicator is negative, it implies no decoupling effect (coupling): emissions grow faster than the economy.

As can be seen in table 2, different results were observed in the two categories of carbon emission in the sub-sample periods. In case of production-based $\mathrm{CO}_{2}$ emissions per capita, the state of relative decoupling has been observed in all sub-sample periods except the period between 1990-1995, indicating that emissions continued to grow, but less rapidly than the rate of economic growth. This is not an ideal scenario for greener economy although it is not a catastrophic scenario for decarbonizing growth.

Table 2: OECD decoupling Indicator for 25 selected African countries (1990-2017)

\begin{tabular}{|c|c|c|c|c|c|}
\hline & $1990-1995$ & $1995-2000$ & $2000-2005$ & $2005-2010$ & $2010-2017$ \\
\hline$\Delta$ Production based $\mathrm{CO}_{2}(\%)$ & 4.753 & 6.815 & 5.986 & 9.368 & 3.778 \\
\hline$\Delta$ Consumption-based $\mathrm{CO}_{2}(\%)$ & 6.095 & 19.069 & 3.197 & 1.748 & 14.525 \\
\hline$\Delta$ GDP per capita, $\mathrm{PPP}(\%)$ & 0.377 & 12.722 & 10.60 & 16.094 & 7.458 \\
\hline Decoupling indicator for PB-CO & $-11.6 * * *$ & $0.46^{*}$ & $0.44^{*}$ & $0.42^{*}$ & $0.49 *$ \\
\hline Decoupling indicator for CB-CO & $-15.2 * * *$ & $-0.5^{* * *}$ & $0.7^{*}$ & $0.89^{*}$ & $-0.95^{* * *}$ \\
\hline
\end{tabular}

Note: $* * *, * *, *$ indicate 'no decoupling', 'absolute decoupling' and 'relative decoupling'. Note that figures for the period between 2010-2017 are taken as averages of two periods: 2010-2014 and 2015-2017 due to the erratic nature of data observed particularly in consumption-based emissions.

In contrast, mixed states of decoupling are revealed in the case of consumption-based emissions per person. No evidence of decoupling is observed in the earlier and late periods of the study (during 1990-2000 and 2010-2017). Economic growth is relatively decoupled from consumption based emissions during 2000-2010 period, however.

\subsection{Econometric Results}

In order to substantiate our results from OECD decoupling method and to examine the impact of international trade on carbon emissions, we employed different panel data estimation techniques. 
Prior to the main econometric analysis, however, we carried out three pre-estimation tests: crosssectional dependence test, panel unit-root test and panel cointegration test as follows:

\subsubsection{Cross-sectional dependence tests}

One of the most common issues involved in panel data analysis is the correlation across panel units (countries) called cross-sectional dependence. Cross-sectional dependence may arise due to the presence of global common shocks and unobserved common factors (spillover effects), spatial dependence, and idiosyncratic pair-wise dependence in the disturbances with no particular pattern of common components (Hoyos \& Sarafldis, 2006; Sarafidis et al., 2008) as well as interactions within socioeconomic networks (Chudik \& Pesaran, 2013). It is very determinative for selecting further econometric tests such as unit root and cointegration tests. As a consequence, failure to account for cross-sectional dependence may affect unbiasedness, consistency, and efficiency properties of standard panel estimators and thus testing for crosssectional dependence is quite essential in estimating panel data models.

Hence, in this study, the CD test proposed by Pesaran $(2004,2015)$ was conducted to check the presence of cross-section dependence across the selected African countries. The Pesaran (2004) CD test is calculated as: $C D=\sqrt{\frac{2 T}{N(N-1)}} \sum_{i-1}^{N-1} \sum_{j=i+1}^{N} \rho_{i j} \sim N(0,1)$

The null hypothesis in CD test assumes the existence of cross-sectional independence (Pesaran, 2004) or weak cross sectional dependence (Pesaran, 2015). The Pesaran (2004, 2015) CD test results are reported in table 3 .

Table 3: Pesaran (2004/2015) CD tests Results

\begin{tabular}{ccccc}
\hline Variables & CD test & P-value & $\begin{array}{c}\text { Correlation } \\
(\text { mean } \boldsymbol{\rho})\end{array}$ & $\begin{array}{c}\text { Absolute } \\
\text { correlation }\end{array}$ \\
\hline $\ln$ PB-CO2 & 65.591 & 0.000 & 0.72 & 0.51 \\
$\ln C B$-CO2 & 51.708 & 0.000 & 0.56 & 0.66 \\
$\ln$ population & 90.48 & 0.000 & 0.99 & 0.99 \\
$\ln$ GDPpc & 57.926 & 0.000 & 0.63 & 0.75 \\
$(\ln \text { GDPpc })^{2}$ & 58.163 & 0.000 & 0.63 & 0.75 \\
$\ln$ Energy & 24.919 & 0.000 & 0.27 & 0.53 \\
$\ln$ Export & 10.599 & 0.000 & 0.12 & 0.35 \\
$\ln$ import & 18.472 & 0.000 & 0.20 & 0.31 \\
\hline
\end{tabular}


The results in table 3 display that the Pesaran (2004) CD test strongly reject the null hypothesis since the CD statistics are statistically significant at $1 \%$. This indicates the existence of crosssectional dependence in all variables across the selected African countries.

\subsubsection{Panel Unit-root test}

Another essential preliminary test is testing data for stationarity to verify the order of integration and to avoid the possibility of spurious regressions in the presence of unit root series. Accordingly, a second generation panel unit-root test called Pesaran (2007) CIPS panel unit-root test was performed in this study since it addresses the issue of cross-sectional dependence by allowing the common factors to have differential effects on different cross-section units and the reduction of the number of required unobserved common factors (Barbieri, 2009).

Table 4: Pesaran (2007) CIPS panel unit-root test results

\begin{tabular}{|c|c|c|c|c|c|}
\hline \multirow{2}{*}{\multicolumn{2}{|c|}{ Variables }} & \multicolumn{3}{|c|}{ Deterministic Specifications of test } & \multirow{2}{*}{$\begin{array}{l}\text { Order of } \\
\text { integration }\end{array}$} \\
\hline & & No intercept & intercept & Intercept + & \\
\hline \multirow{2}{*}{$\ln \mathrm{PB}-\mathrm{CO} 2$} & Level, I(0) & -1.309 & -1.909 & $-2.902 *$ & \multirow[t]{2}{*}{$\mathrm{I}(1)$} \\
\hline & First difference, I(1) & $-4.859 *$ & $-5.018^{*}$ & $-5.178 *$ & \\
\hline \multirow[t]{2}{*}{$\ln \mathrm{CB}-\mathrm{CO} 2 \mathrm{pc}$} & Level, I(0) & -1.417 & -1.838 & -2.548 & \multirow[t]{2}{*}{$\mathrm{I}(1)$} \\
\hline & First difference, I(1) & $-5.149 *$ & $-5.642 *$ & $-5.787 *$ & \\
\hline \multirow[t]{2}{*}{ In population } & Level, I(0) & -1.004 & $-2.716^{*}$ & -2.563 & \multirow[t]{2}{*}{$\mathrm{I}(1)$} \\
\hline & First difference, I(1) & $-2.643 *$ & $-2.799 *$ & $-3.586^{*}$ & \\
\hline \multirow[t]{2}{*}{ ln GDPpc } & Level, I(0) & -1.539 & -1.582 & -1.845 & \multirow[t]{2}{*}{$\mathrm{I}(1)$} \\
\hline & First difference, I(1) & $-3.216^{*}$ & $-3.722 *$ & $-4.150 *$ & \\
\hline \multirow[t]{2}{*}{$(\ln \mathrm{GDPpc})^{2}$} & Level, I(0) & -1.511 & -1.584 & -1.857 & \multirow[t]{2}{*}{$\mathrm{I}(1)$} \\
\hline & First difference, I(1) & $-3.380 *$ & $-3.845^{*}$ & $-4.172 *$ & \\
\hline \multirow[t]{2}{*}{ ln Energy } & Level, I(0) & -1.436 & -2.028 & -2.085 & \multirow[t]{2}{*}{$\mathrm{I}(1)$} \\
\hline & First difference, I(1) & $-4.477 *$ & $-4.785^{*}$ & $-4.961 *$ & \\
\hline \multirow[t]{2}{*}{ ln export } & Level, I(0) & -1.923 & -1.940 & -2.552 & \multirow[t]{2}{*}{$\mathrm{I}(1)$} \\
\hline & First difference, I(1) & $-5.008 *$ & $-5.040^{*}$ & $-5.159 *$ & \\
\hline \multirow[t]{2}{*}{ ln import } & Level, I(0) & $-2.308 *$ & $-2.558 *$ & $-2.706^{* *}$ & \multirow[t]{2}{*}{$\mathrm{I}(0)$} \\
\hline & First difference, I(1) & - & - & $-5.198 *$ & \\
\hline
\end{tabular}

Note: $* * *$ and $* * *$ denote statistically significant at $1 \%, 5 \%$, and $10 \%$ levels respectively. The critical values of CIPS test at $1 \%, 5$ and $10 \%$ significance levels are: $-1.47,-1.57$ and -1.74 for no intercept nor trend; $-2.07,-2.15, \&$ 2.30 for intercept, and $-2.58,-2.66$ and -2.81 for intercept + trend respectively. 
The null hypothesis of CIPS test is that all the data series contain unit roots (variables are nonstationary). As can be seen in table 4, the Pesaran (2007) CIPS test results show that all variables except import are found stationary at their first differences (i.e. they are I(1)).

\subsubsection{Panel Cointegration test}

The cointegration test indicates that whether non-stationary variables are co-integrated in a sense that there exists a long run relationship among variables across the selected countries in the model. Hence, we carried out heterogeneous panel cointegration test proposed by Pedroni (1999, 2004) in this study. Under the null hypothesis of no cointegration relationship, Pedroni cointegration test computes seven test statistics, which are asymptotically distributed to a onesided standard normal distribution, with two categories: panel and group tests. According to Pedroni (1999), the panel tests (within dimension-based statistic) include four statistics: panel vstatistic, panel rho-statistic, panel pp-statistic and panel ADF-statistic. On the other hand, the group tests (between dimension-based) include three statistics: group rho-statistic, group ppstatistic and group ADF-statistic. However, Pedroni cointegration test relies on a quite restrictive assumption of cross-sectional independence in the error term. In this regard, one of the common ways to address the issue of cross sectional dependence is demeaning ${ }^{10}$ of the data so as to remove any common time-varying shocks (Hoyos \& Sarafldis, 2006; Sarafidis et al., 2008). Hence, we performed Pedroni cointegration test on the demeaned data since the CD tests performed in section (4.3.1) detected the existence of cross-section dependence.

\begin{tabular}{cccc}
\hline \multirow{2}{*}{ Statistic } & $\begin{array}{c}\text { When } \ln \text { PB-CO2 is a } \\
\text { dependent variable } \\
\text { Test statistic }\end{array}$ & $\begin{array}{c}\text { When } \ln \text { CB-CO2 is a } \\
\text { dependent variable }\end{array}$ \\
\cline { 2 - 4 } & & $-2.042^{* *}$ & Test statistic \\
\hline \multirow{3}{*}{$\begin{array}{c}\text { Panel statistic } \\
\text { (within dimension) }\end{array}$} & Panel v & $3.574^{*}$ & $-2.439^{*}$ \\
\cline { 2 - 4 } & Panel rho- & $-3.443^{*}$ & $2.82^{*}$ \\
\cline { 2 - 4 } & Panel pp & $-4.282^{*}$ & $-6.24^{*}$ \\
\hline \multirow{2}{*}{$\begin{array}{c}\text { Group Statistic } \\
\text { (Between dimension) }\end{array}$} & Group rho & $5.065^{*}$ & $-5.784^{*}$ \\
\cline { 2 - 4 } & Group pp & $-3.163^{*}$ & $4.57^{*}$ \\
\cline { 2 - 4 } & Group ADF & $-2.703^{*}$ & $-6.301^{*}$ \\
\hline
\end{tabular}

Table 5: Pedroni $(1999,2004)$ cointegration test results

\footnotetext{
${ }^{10}$ Data demeaning refers to transforming the observations in terms of deviations from time-specific averages. $\left(y_{i t}^{\text {demean }}=y_{i t}-\bar{y}_{t}\right.$, where $\left.\bar{y}_{t}=\frac{1}{N} \sum_{i=1}^{N} y_{i t}\right)$. see Hoyos and Sarafldis (2006); Sarafidis et al.(2008).
} 
Note: $*$ and $* *$ denote statistically significant at $1 \%$ and $5 \%$ levels respectively. The critical values of a one-tailed standard normal test at 1\%, 5 and 10\% significance levels are: -2.326, -1.645, and -1.282.

The Pedroni cointegration test results reported in table 5 indicate the existence of cointegration relationship in both production-based and consumption-based analyses, suggesting a stable long run relationship among variables of the study. As a robustness check, we employed Pesaran (2007) CIPS test on the residuals of CCE-MG and AMG estimations and the results reveal that residuals are $\mathrm{I}(0)$, which confirm the existence of cointegration in our study (see table 6 ).

\subsubsection{Econometric Estimation Results ${ }^{11}$}

The CCE-MG, AMG and DOLS estimators were mainly employed to estimate the extended STRIPAT model stated in equation (3). The results are reported in table 6. In our estimations where production-based $\mathrm{CO}_{2}$ emissions is a dependent variable, the results from all estimators show that turning point (the threshold level of GDP per capita) is located well within the given data range of GDP per capita but above the sample average and further the coefficient of quadratic term is negative but statistically insignificant (except the DOLS estimate). This suggests that the falling part of EKC curve remains shorter and flattened compared to the rising part of the curve, and thus the true relationship between production-based $\mathrm{CO}_{2}$ emissions and economic growth lies on the first half (rising part) of EKC curve ${ }^{\mathbf{1 2}}$. Hence, all estimation results confirm some evidence of relative decoupling of growth from territorial carbon emissions in

\footnotetext{
${ }^{11}$ Since including the linear and quadratic term of GDP per capita in a regression causes high correlation between the two terms, which in turn leads to highly inflated standard errors. As a result, we did mean-centering for GDP per capita and used in the analysis in order to remove this non-essential correlation and obtain meaningful statistical inferences. We found, in case of mean-centering, the correlation between the two terms much more manageable.

${ }^{12}$ In standard EKC framework, relative decoupling is represented in the rising part of EKC curve, while the falling part of the curve ( i.e. beyond the turning point) indicates absolute decoupling (see Mikayilov et al., 2018). Similarly, Pilatowska and Wlodarczyk (2018) noted that for countries exhibiting relative decoupling, the falling branch of the EKC curve is shorter and flattened in comparison to the raising branch.
} 
Africa over the last three decades, reflecting production emissions continue to grow, but at a slower rate compared to economic growth.

On the other hand, the CCE-MG and AMG estimation results using consumption-based $\mathrm{CO} 2$ emissions reveal that the consumption-related emissions are not decoupled from economic growth within our sample range since we found insignificant coefficients of quadratic term and no turning point in $\mathrm{AMG}$ estimation results. The turning point in CCE-MG results is also quite close to the upper limit of the data. In contrast, the DOLS results indicate a small degree of decoupling between consumption-based emissions and growth.

Table 6: CCE-MG, AMG and DOLS ${ }^{13}$ Estimation results

\begin{tabular}{|c|c|c|c|c|c|c|}
\hline \multirow[t]{2}{*}{ Variables } & \multicolumn{3}{|c|}{$\begin{array}{c}\text { when } \ln \mathrm{PB}-\mathrm{CO} 2 \text { is a dependent } \\
\text { variable }\end{array}$} & \multicolumn{3}{|c|}{$\begin{array}{c}\text { when } \ln \mathrm{CB}-\mathrm{CO} 2 \text { is a dependent } \\
\text { variable }\end{array}$} \\
\hline & CCE-MG & $\mathrm{AMG}$ & DOLS & CCE-MG & AMG & DOLS \\
\hline ln population & $\begin{array}{l}3.524 \\
(3.25)\end{array}$ & $\begin{array}{l}1.656^{*} \\
(0.275)\end{array}$ & $\begin{array}{l}5.144^{*} \\
(0.051)\end{array}$ & $\begin{array}{l}-3.329 \\
(3.022)\end{array}$ & $\begin{array}{l}1.311^{*} \\
(0.261)\end{array}$ & $\begin{array}{l}6.945^{*} \\
(0.067)\end{array}$ \\
\hline ln GDPpc & $\begin{array}{r}1.501 * * \\
(0.683)\end{array}$ & $\begin{array}{l}1.866^{* *} \\
(0.882)\end{array}$ & $\begin{array}{l}2.312^{*} \\
(0.028)\end{array}$ & $\begin{array}{l}1.017 \\
(0.963)\end{array}$ & $\begin{array}{l}1.579 * * \\
(0.704)\end{array}$ & $\begin{array}{l}1.204 * \\
(0.066)\end{array}$ \\
\hline$(\ln \mathrm{GDPpc})^{2}$ & $\begin{array}{l}-0.673 \\
(0.632)\end{array}$ & $\begin{array}{l}-0.580 \\
(0.575)\end{array}$ & $\begin{array}{l}-1.405^{*} \\
(0.013)\end{array}$ & $\begin{array}{l}-0.29 \\
(0.536)\end{array}$ & $\begin{array}{l}-0.372 \\
(0.655)\end{array}$ & $\begin{array}{l}-0.573 * \\
(0.088)\end{array}$ \\
\hline ln Energy & $\begin{array}{c}0.92^{*} \\
(0.344)\end{array}$ & $\begin{array}{l}1.461^{* *} \\
(0.615)\end{array}$ & $\begin{array}{l}4.241^{*} \\
(0.051)\end{array}$ & $\begin{array}{c}0.04 \\
(0.149)\end{array}$ & $\begin{array}{r}0.373 * * \\
(0.188)\end{array}$ & $\begin{array}{l}1.651^{*} \\
(0.07)\end{array}$ \\
\hline ln Export & $\begin{array}{l}-0.111 \\
(0.099)\end{array}$ & $\begin{array}{l}-0.084 \\
(0.086)\end{array}$ & $\begin{array}{l}0.911^{*} \\
(0.005)\end{array}$ & $\begin{array}{l}-0.217 * * \\
(0.085)\end{array}$ & $\begin{array}{l}-0.14 * * \\
(0.067)\end{array}$ & $\begin{array}{l}-0.721^{*} \\
(0.041)\end{array}$ \\
\hline ln import & $\begin{array}{c}0.115 \\
(0.114)\end{array}$ & $\begin{array}{c}0.106 \\
(0.075)\end{array}$ & $\begin{array}{l}-1.003 * \\
(0.007)\end{array}$ & $\begin{array}{l}0.179 * \\
(0.068)\end{array}$ & $\begin{array}{l}0.095 \\
(0.069)\end{array}$ & $\begin{array}{l}1.827 * \\
(0.051)\end{array}$ \\
\hline $\begin{array}{l}\text { Wald-test } \\
\text { [p-value] }\end{array}$ & $\begin{array}{c}21.17 \\
{[0.002]}\end{array}$ & $\begin{array}{c}51.97 \\
{[0.000]}\end{array}$ & - & $\begin{array}{c}15.03 \\
{[0.020]}\end{array}$ & $\begin{array}{c}15.11 \\
{[0.019]}\end{array}$ & - \\
\hline RMSE & 0.049 & 0.081 & 0.096 & 0.081 & 0.112 & 0.235 \\
\hline $\begin{array}{c}\mathrm{R}^{2} \\
{\left[\mathrm{Adj}-\mathrm{R}^{2}\right]}\end{array}$ & - & - & $\begin{array}{c}0.97 \\
{[0.92]}\end{array}$ & & & $\begin{array}{c}0.88 \\
{[0.76]}\end{array}$ \\
\hline $\begin{array}{l}\text { Order of } \\
\text { integration }\end{array}$ & $\mathrm{I}(0)$ & $\mathrm{I}(0)$ & - & $\mathrm{I}(0)$ & $\mathrm{I}(0)$ & - \\
\hline $\begin{array}{l}\text { CD test } \\
\text { [p-value }]\end{array}$ & $\begin{array}{l}-2.232 \\
{[0.03]}\end{array}$ & $\begin{array}{l}-1.679 \\
{[0.09]}\end{array}$ & - & $\begin{array}{c}0.094 \\
{[0.925]}\end{array}$ & $\begin{array}{c}-1.278 \\
{[0.201]}\end{array}$ & - \\
\hline $\begin{array}{l}\text { Turning } \\
\text { point }\end{array}$ & $\begin{array}{c}1.116 \\
{[-1.95,2.08]}\end{array}$ & $\begin{array}{c}1.608 \\
{[-1.95,2.08]}\end{array}$ & $\begin{array}{c}0.822 \\
{[-1.95,2.08]}\end{array}$ & $\begin{array}{c}1.75 \\
{[-1.95,2.08]}\end{array}$ & - & $\begin{array}{c}1.05 \\
{[-1.95,2.08]}\end{array}$ \\
\hline
\end{tabular}

\footnotetext{
${ }^{13}$ Note that DOLS estimator assumes cross-sectional independence, which is unlikely to be valid in practice. As a result, we applied this estimator on demeaned data instead of the original (raw) one so as to deal with the issue of cross-sectional dependence.
} 


\section{Interval}

Note: The figures shown in brackets are standard errors. * and ** denote statistically significant at $1 \%$ and 5\% levels respectively. Order of integration of the residuals is determined from the Pesaran (2007) CIPS test: I( 0$)=$ stationary. The post-estimation CD test is the test statistic from Pesaran (2004, 2015) CD test, assuming a null hypothesis that the residuals are cross-sectional independent or weakly cross-sectional dependent.

To summarize, the estimation results from CCE-MG, AMG and DOLS estimators invariably confirm the occurrence of relative (weak) state of decoupling in production-based $\mathrm{CO}_{2}$ emissions, and no robust evidence of decoupling for consumption-based emissions in the selected African countries over the study period. Our estimation results are quite similar to the findings reported in Knight and Schor (2014); Mir and Storm (2016), and Schroder and storm (2018). This implies that growth is strongly linked with consumption-based emissions than territorial emissions. The results further indicate that the environmental pollution abatement measures and climate-related policies in Africa are not still fully-effective in reducing carbon emissions. In addition, considering emissions generated at the point of production alone would evidently be insufficient for mitigation policies and efforts and thus for addressing climate change. This calls for the inclusion of emissions embodied in international trade as well in emissions reduction target setting and climate negotiations to be effective in limiting global carbon emissions.

Coming to other factors, all estimators consistently indicate that primary energy intensity is found to have a significant positive influence on both production and consumption-related carbon emissions. Population size has also a significant positive effect on both types of emissions. Hence, energy intensity and size of population are found as main driving forces of carbon emissions in Africa. With regard to the role of international trade, as expected, trade flows (exports and imports) share do not have any significant impact on production-based carbon emissions in CCE-MG and AMG estimation results, while they are found to have significant and offsetting effect for consumption-based emissions in all estimators. Exports have a negative effect, while imports have a positive effect on consumption-related emissions. Similar results were reported in Knight and Schor (2014); Hasanov et al. (2018) and Liddle (2018).

\section{Conclusions and Policy Implications}

This study investigates whether economic growth in Africa could be decoupled from carbon emissions over the last three decades (1990-2017). The effect of trade flows (considering exports 
and imports share of GDP separately) on carbon emissions is also assessed. This study essentially differs from previous related studies as it considers both production and consumptionbased carbon emissions. Further, it employed both decoupling indicator and econometric techniques so as to substantiate our results in decoupling analysis. In particular, we used panel estimation approaches which account for serious methodological issues like cross-sectional dependence, heterogeneity, endogeneity and serial correlation, which were oftentimes ignored in previous empirical works. Concerning to our findings, the OECD decoupling indicator and econometric estimation results invariably support the existence of relative (weak) decoupling of production-based carbon emissions and economic growth and no robust evidence of decoupling in case of consumption-related emissions. Further, our main econometric estimation results indicate that exports and imports are found to have significant effects of opposite signs on consumption emissions, but are insignificant for territorial emissions as expected.

Some possible policy implications are suggested below in light of the our findings and conclusions. Weaker evidence of decoupling of growth from territorial emissions and no vigorous evidence found at all for consumption-based emissions together indicate that climate policy measures in Africa are not fully-effective in mitigating carbon emissions. Hence, specific and active policy interventions like reducing primary energy intensity, promoting cost-effective green innovations, and reforestation programs should be put in place. The results of this study also suggest for global community to give more emphasis for consumption-based carbon emissions in international climate negotiations and target setting discussions as territorial emissions do not explicitly account for emissions associated with international trade, and do not provide a more complete picture of total emissions. Further, our results recommend imposing carbon taxes not only on direct polluters, but also on final consumers of carbon-intensive goods and services too (consumption-based carbon emissions regulation should also be enforced). In general, it is quite worthwhile (i) to look at production and consumption perspectives in emissions-growth relationship and (ii) consider trade variables (imports and exports) separately in exploring the role of international trade on emissions.

\section{Acknowledgements}

None. 


\section{Authors' contributions}

This work is the original contribution by the author. The author read and approved the final manuscript.

\section{Funding}

No funding was received.

\section{Competing interests}

The author declares no competing interest.

\section{Availability of data and materials}

The data used in this study will be available upon request.

\section{References}

Afionis, S., Sakai, M., Scott, K., Barrett, J. and Gouldson, A. (2017). Consumption-based carbon accounting: does it have a future? WIREs Climate Change, 8.

African Economic Outlook (2020). Developing Africa's Workforce for the Future. African Development Bank Group: Abidjan, Côte d'Ivoire.

Barbieri, L. (2009). Panel Unit Root Tests under Cross-Sectional Dependence: An Overview. Journal of Statistics: Advances in Theory and Applications, 1(2):117-158.

Baumert, N., Kander, A., Jiborn, M., Kulionis, V. and Nielsen, T. (2019). Global outsourcing of carbon emissions 1995-2009: A reassessment. Environmental Science and Policy, 92: 228-236.

Bhowmik, D. (2019). Decoupling CO2 Emissions in Nordic countries: Panel Data Analysis. SocioEconomic Challenges, 3(2).

Boden, T.A., Marland, G. and Andres, R.J. (2017). Global, Regional, and National Fossil-Fuel CO2 Emissions, Carbon Dioxide Information Analysis Center, Oak Ridge National Laboratory, U.S. Department of Energy.

Chudik, A. and Pesaran M.H. (2013). Large Panel Data Models with Cross-Sectional Dependence: A Survey. Federal Reserve Bank of Dallas, Globalization and Monetary Policy Institute, Working Paper No. 153.

Cohen, G., Jalles, J.T., Loungani, P. and Marto, R. (2018). The Long-Run Decoupling of Emissions and Output: Evidence from the Largest Emitters. IMF Working Paper, WP/18/56.

Dietz, T., Rosa, E.A. (1994). Rethinking the environmental impacts of population, affluence and technology. Human Ecology Review, 1: 277-300.

Eberhardt, M. (2012). Estimating panel time-series models with heterogeneous slopes, Stata Journal, 12: 61-71.

Eberhardt, M. and Teal, F. (2010). Productivity Analysis in Global Manufacturing Production. Economics Series Working Papers 515, University of Oxford, Department of Economics.

Eberhardt, M., and Teal, F. (2011). Econometrics for grumblers: a new look at the literature on cross- country growth empirics. Journal of Economic Surveys, 25(1):109-155.

Farhani, S., Mrizak S., Chaibi A. and Rault C. (2014). The environmental Kuznets curve and sustainability: A panel data analysis. IPAG Business School working paper No. 2014 (300). 
Feng, S. (2017). The Driving Factor Analysis of China's $\mathrm{CO}_{2}$ Emissions Based on the STIRPAT Model. Open Journal of Social Sciences, 5: 49-58.

Hasanov, F.J., Liddle, B. and Mikayilov, J.I. (2018). Impact of International Trade on $\mathrm{CO}_{2}$ emissions in oil exporting countries: Territory vs consumption emissions accounting. Energy Economics, 74: 343-350.

Hilmi, N., Acar, S.,Safa, A. and Bonnemaison, G. (2018). Decoupling Economic Growth and $\mathrm{CO}_{2}$ Emissions in the MENA: Can It Really Happen? Proceedings of Middle East Economic Association, 20(2).

Hossfeld, O. (2010). Equilibrium Real Effective Exchange Rates and Real Exchange Rate Misalignments: Time Series vs. Panel Estimates. International Network for Economic Research, Working Paper, 2010.3 .

Hoyos, R.E. and Sarafidis, B. (2006). Testing for cross-sectional dependence in panel-data models. The Stata Journal, 6(4): 482-496.

Jiborn, M., Kander, A., Kulionis, V., Nielsen, H. and Moran, D.D. (2018). Decoupling or delusion? Measuring emissions displacement in foreign trade. Global Environmental Change, 49:27-34.

Karakaya, E., Yilmaz, B. and Alatas, S. (2018). How Production Based and Consumption Based Emissions Accounting Systems Change Climate Policy Analysis: The Case of $\mathrm{CO}_{2}$ Convergence. MPRA Paper No. 88781.

Knight, K.W. and Schor, J.B. (2014). Economic Growth and Climate Change: A Cross-National Analysis of Territorial and Consumption-Based Carbon Emissions in High-Income Countries. Sustainability, 6: 3722-3731.

Le-Le, Z., Xiu-Qing, S., Yi, Y. and Xiao-Wei, M. (2016). Decoupling Economic growth $\mathrm{CO}_{2}$ emissions: A decomposition analysis of China's household energy consumption. Advances in Climate Change Research, 7: 192-200.

Liddle, B. (2018). Consumption-Based Accounting and the Trade-Carbon Emissions Nexus in Asia: A Heterogeneous, Common Factor Panel Analysis. Sustainability, 10: 3627.

Lin, S., Beidari, M., and Lewis, C. (2015). Energy Consumption Trends and Decoupling Effects between Carbon Dioxide and Gross Domestic Product in South Africa. Aerosol and Air Quality Research, 15: 2676-2687.

Mikaylov, J.I., Hasanov, F.J., and Galeotti, M. (2018). Decoupling of CO2 emissions and GDP: A timevarying cointegration approach. Ecological Indicators, 95: 615-628.

Mir, G.U.R., and Storm, S. (2016). Carbon Emissions and Economic Growth: Production-based versus Consumption-based Evidence on Decoupling. Institute of New Economic Thinking, Working Paper No. 41.

Mitic, P., Ivanovic, O.M. and Zdravkovi'c, A. (2017). A Cointegration Analysis of Real GDP and $\mathrm{CO}_{2}$ Emissions in Transitional Countries. Sustainability, 9: 568.

Moro, R. (2016). Economic Development and Sustainability in Africa. Background Paper No. 1, Italian Institute for International Political Studies, Milano.

Nordic Council of Ministers (2006). Measuring sustainability and decoupling: A survey of methodology and practice. TemaNord 2006:580, ISBN 92-893-1410-9.

OECD (2002). Indicators to Measure Decoupling of Environmental Pressure from Economic Growth. Sustainable Development, SG/SD/(2002)1/Final.

Pedroni, P. (1999). Critical Values for Cointegration Tests in Heterogeneous Panels with Multiple Regressors. Oxford Bulletin of Economics and Statistics, 61:653-70.

Pedroni, P. (2004). Panel Cointegration: Asymptotic and Finite Sample Properties of Pooled Time Series Tests with an Application to the PPP Hypothesis. Econometric Theory, 20: 597-625.

Pesaran, M. H. (2004). General Diagnostic Tests for Cross Section Dependence in Panels. Cambridge Working Papers in Economics No. 435 and CESifo Working Paper Series 1229.

Pesaran, M. H. (2006). Estimation and inference in large heterogeneous panels with a multifactor error structure. Econometrica, 74(4): 967-1012. 
Pesaran, M. H. (2007). A Simple Panel Unit Root Test in the Presence of Cross-Section Dependence. Journal of Applied Econometrics, 22 (2): 265-312.

Pesaran, M. H. (2015). Testing Weak Cross-Sectional Dependence in Large Panels. Econometric Reviews, 34 (6-10):1089-117.

Peters, G.P., Minx, J.C., Weber, L. and Edenhofer, O. (2011). Growth in emission transfers via international trade from 1990 to 2008. Proceedings of the National Academy of Sciences, USA.

Piłatowska, M. and Włodarczyk, A. (2018). Decoupling Economic Growth From Carbon Dioxide Emissions in the EU Countries. Montenegrin Journal of Economics, 14(1): 7-26.

Ru, X., Chen, S., and Dong, H. (2012). An Empirical Study on Relationship between Economic Growth and Carbon Emissions Based on Decoupling Theory. Journal of Sustainable Development, 5(8).

Sarafidis, V., Yamagata, T. and Robertson, D. (2008). A test of cross section dependence for a linear dynamic panel model with regressors. Journal of Econometrics.

Schroder, E. and Storm, S. (2018). Economic Growth and Carbon Emissions: The Road to 'Hothouse Earth' is Paved with Good Intentions. Delft University of Technology.

UNCTAD (2020). UNCTADstat open data. United Nations Conference on Trade and Development, Geneva.

Vavrek, R. and Chovancova, J. (2016). Decoupling of Greenhouse Gas Emissions from Economic Growth in V4 countries. Procedia Economics and Finance 39: 526 - 533.

Wu, Y., Zhu, Q. and Zhu, B. (2018). Decoupling analysis of world economic growth and CO2 emissions: A study comparing developed and developing countries. Journal of Cleaner Production, 190: 94103.

York, R., Rosa, E.A. and Dietz, T. (2003). STIRPAT, IPAT and ImPACT: analytic tools for unpacking the driving forces of environmental impacts. Ecological Economics, 46: 351-365.

\section{Appendix-1}

Table A1: Review of some recent studies on Decoupling

\begin{tabular}{|c|c|c|c|c|}
\hline Studies & $\begin{array}{l}\text { Study area } \\
\text { \& period }\end{array}$ & $\begin{array}{l}\text { Methodology } \\
\text { employed }\end{array}$ & $\begin{array}{l}\text { Main Variables } \\
\text { included }\end{array}$ & Main Findings of the studies \\
\hline $\begin{array}{l}\text { Mir \& Storm } \\
\quad(2016)\end{array}$ & $\begin{array}{l}27 \text { EU and } \\
13 \text { Non-EU } \\
\text { countries } \\
(1995-2207)\end{array}$ & $\begin{array}{c}\text { Panel Fixed Effects } \\
\text { Model }\end{array}$ & $\begin{array}{l}\text { Production-based \& } \\
\text { Consumption-based } \\
\mathrm{CO}_{2} \text { emissions, GDP }\end{array}$ & $\begin{array}{l}\text { Evidence of Decoupling } \\
\text { between production-based } \mathrm{CO}_{2} \\
\text { emissions and growth. }\end{array}$ \\
\hline $\begin{array}{l}\text { Hilmi et al. } \\
\text { (2018) }\end{array}$ & $\begin{array}{c}\text { MENA } \\
\text { countries } \\
(1960-2013)\end{array}$ & $\begin{array}{c}\text { Panel Fixed Effects } \\
\text { Model }\end{array}$ & $\begin{array}{c}\mathrm{CO}_{2} \text { emissions, } \\
\mathrm{GDP} \text {, energy use, } \\
\text { industry, renewables } \\
\text { and waste, population }\end{array}$ & $\begin{array}{l}\text { no evidence for decoupling of } \\
\mathrm{CO} 2 \text { emissions from economic } \\
\text { growth }\end{array}$ \\
\hline $\begin{array}{l}\text { Piłatowska \& } \\
\text { Włodarczyk } \\
\text { (2018) }\end{array}$ & $\begin{array}{c}14 \mathrm{EU} \\
\text { countries } \\
(1960-2012)\end{array}$ & $\begin{array}{c}\text { Threshold } \\
\text { cointegration } \\
\text { model }\end{array}$ & $\begin{array}{l}\mathrm{CO}_{2} \text { emissions per } \\
\text { capita, GDP and } \\
\text { energy consumption }\end{array}$ & $\begin{array}{l}\text { Evidence of decoupling in five } \\
\text { countries }\end{array}$ \\
\hline $\begin{array}{l}\text { Mikaylov et } \\
\text { al. (2018) }\end{array}$ & $\begin{array}{l}12 \text { Western } \\
\text { EU countries } \\
(1861-2015)\end{array}$ & $\begin{array}{l}\text { Time-varying } \\
\text { cointegration } \\
\text { approach }\end{array}$ & $\begin{array}{c}\mathrm{CO}_{2} \text { emissions and } \\
\text { GDP }\end{array}$ & $\begin{array}{l}\text { Evidence of relative } \\
\text { decoupling in } 8 \text { countries }\end{array}$ \\
\hline $\begin{array}{l}\text { Lin et al. } \\
\quad(2015)\end{array}$ & $\begin{array}{l}\text { South Africa } \\
(1990-2012)\end{array}$ & $\begin{array}{c}\text { OECD (2002), } \\
\text { Tapio(2005) model } \\
\text { \& Kaya Identity }\end{array}$ & $\begin{array}{l}\mathrm{CO}_{2} \text { emissions, GDP } \\
\text { energy consumption, } \\
\text { population }\end{array}$ & $\begin{array}{l}\text { Evidence of strong decoupling } \\
\text { during 2010-2012 and weak } \\
\text { decoupling during 1994-2010 }\end{array}$ \\
\hline $\begin{array}{l}\text { Cohen et al. } \\
\qquad(2018)\end{array}$ & $\begin{array}{c}20 \text { largest } \\
\text { GHG emitters } \\
(1960-2014)\end{array}$ & $\begin{array}{l}\text { trend/cycle } \\
\text { decomposition } \\
\text { analysis }\end{array}$ & $\begin{array}{c}\text { Production and } \\
\text { consumption based } \\
\text { GHG emissions, GDP } \\
\text { per-capita, }\end{array}$ & $\begin{array}{l}\text { Weaker evidence of } \\
\text { decoupling between trend } \\
\text { emissions and trend GDP }\end{array}$ \\
\hline
\end{tabular}




\begin{tabular}{|c|c|c|c|c|}
\hline $\begin{array}{l}\text { Schröder and } \\
\text { Storm (2018) }\end{array}$ & $\begin{array}{l}61 \text { OECD \& } \\
\text { non-OECD } \\
(1995-2011)\end{array}$ & $\begin{array}{c}\text { Kaya identity } \\
\text { Panel Fixed effects } \\
\text { model }\end{array}$ & $\begin{array}{l}\text { Production-based \& } \\
\text { Consumption-based } \\
\mathrm{CO}_{2} \text { emissions, GDP }\end{array}$ & $\begin{array}{l}\text { evidence for a decoupling of } \\
\text { production-based } \mathrm{CO}_{2} \\
\text { emissions and growth }\end{array}$ \\
\hline $\begin{array}{l}\text { Jiborn } \text { et al. } \\
\quad(2018)\end{array}$ & $\begin{array}{l}\text { UK and } \\
\text { Sweden } \\
(1995-2009)\end{array}$ & $\begin{array}{l}\text { Environmentally } \\
\text { extended input- } \\
\text { output analysis }\end{array}$ & $\begin{array}{l}\text { technology-adjusted } \\
\text { balance of emissions } \\
\text { embodied in trade }\end{array}$ & $\begin{array}{l}\text { No evidence of decoupling in } \\
\text { both countries }\end{array}$ \\
\hline $\begin{array}{l}\text { Le-Le } \text { et al. } \\
\quad(2016)\end{array}$ & $\begin{array}{c}\text { China } \\
(1994-2012)\end{array}$ & $\begin{array}{l}\text { Logarithmic mean } \\
\text { Divisia Index } \\
\text { (LDMI) model }\end{array}$ & $\begin{array}{l}\text { Household } \mathrm{CO}_{2} \\
\text { emissions and GDP } \\
\text { growth }\end{array}$ & $\begin{array}{l}\text { Evidence of weak decoupling } \\
\text { of household } \mathrm{CO}_{2} \text { emissions }\end{array}$ \\
\hline $\begin{array}{l}\text { Vavrek and } \\
\text { Chovancova } \\
(2016)\end{array}$ & $\begin{array}{l}\text { V4 countries } \\
(1991-2012)\end{array}$ & $\begin{array}{l}\text { decoupling } \\
\text { indicators }\end{array}$ & $\begin{array}{l}\text { GHG emissions and } \\
\text { GDP }\end{array}$ & $\begin{array}{l}\text { Evidence of strong decoupling } \\
\text { of GHG emissions from GDP }\end{array}$ \\
\hline $\begin{array}{l}\text { Ru et al. } \\
\text { (2012) }\end{array}$ & $\begin{array}{l}6 \text { developed \& } \\
3 \text { developing } \\
\text { countries } \\
(1960-2007)\end{array}$ & $\begin{array}{l}\text { Tapio's decoupling } \\
\text { indicators }\end{array}$ & $\begin{array}{c}\mathrm{CO}_{2} \text { emissions and } \\
\text { GDP }\end{array}$ & $\begin{array}{l}\text { Evidence of strong decoupling } \\
\text { in developed countries, but not } \\
\text { developing countries. }\end{array}$ \\
\hline $\begin{array}{l}\text { Bhowmik } \\
\text { (2019) }\end{array}$ & $\begin{array}{c}\text { Nordic } \\
\text { countries } \\
(1970-2016)\end{array}$ & $\begin{array}{l}\text { Panel Fixed effects } \\
\text { regression model }\end{array}$ & $\begin{array}{l}\mathrm{CO}_{2} \text { emissions and } \\
\text { GDP per capita }\end{array}$ & $\begin{array}{l}\text { Evidence of decoupling only in } \\
\text { two countries }\end{array}$ \\
\hline $\begin{array}{l}\text { Wu et al. } \\
(2018)\end{array}$ & $\begin{array}{c}\text { Developed \& } \\
\text { developing } \\
\text { countries }\end{array}$ & $\begin{array}{l}\text { OECD, Tapio elastic } \\
\text { analysis method, and } \\
\text { IGTX decoupling } \\
\text { model }\end{array}$ & $\begin{array}{l}\mathrm{CO}_{2} \text { emissions and } \\
\text { GDP }\end{array}$ & $\begin{array}{l}\text { Evidence of strong decoupling } \\
\text { for developed countries and } \\
\text { weak decoupling for } \\
\text { developing countries }\end{array}$ \\
\hline
\end{tabular}

\section{Appendix-2}

Figure A1: Per-capita Production and Consumption-based $\mathrm{CO}_{2}$ emissions in 1995 and 2015

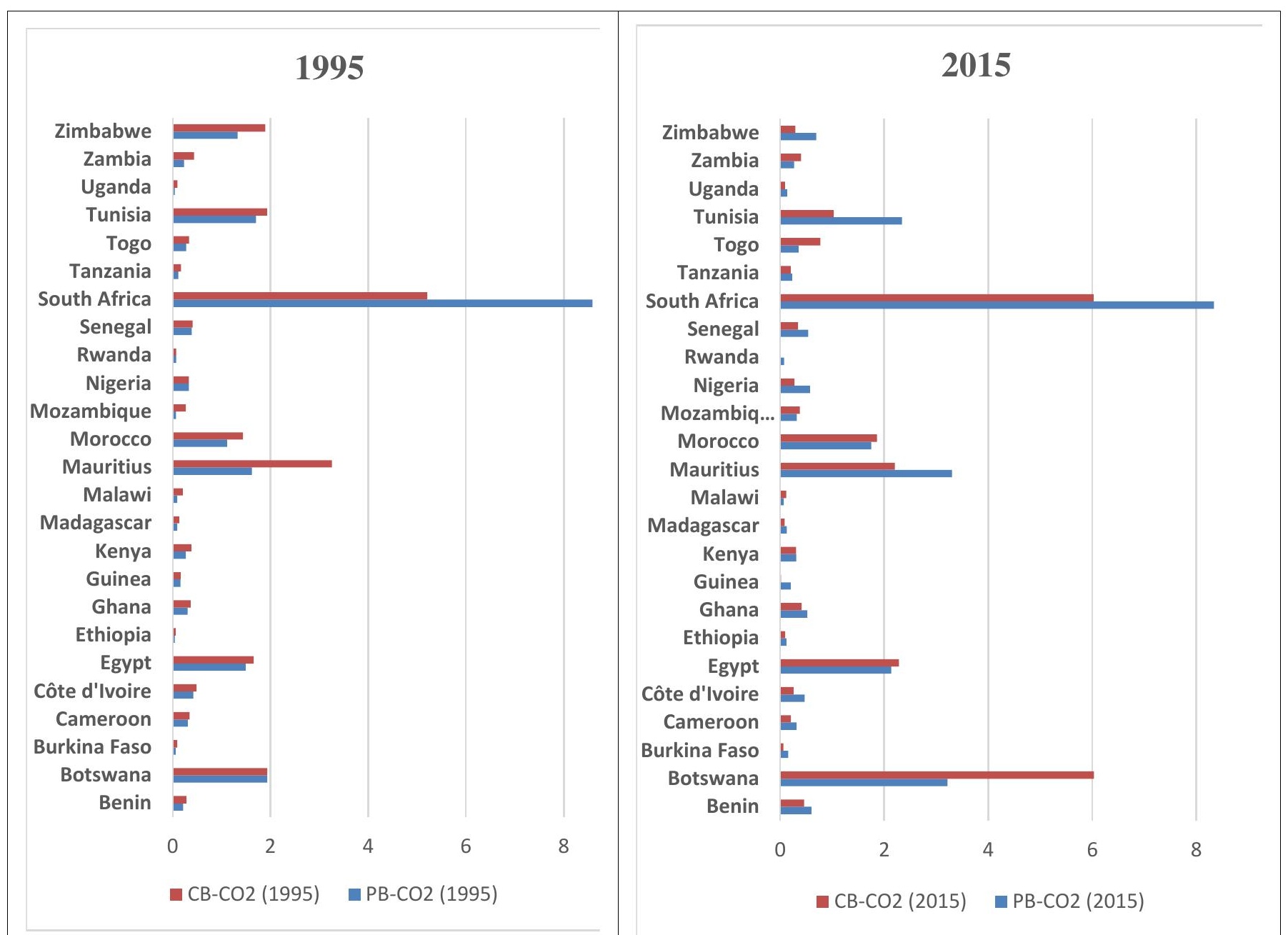


Figures

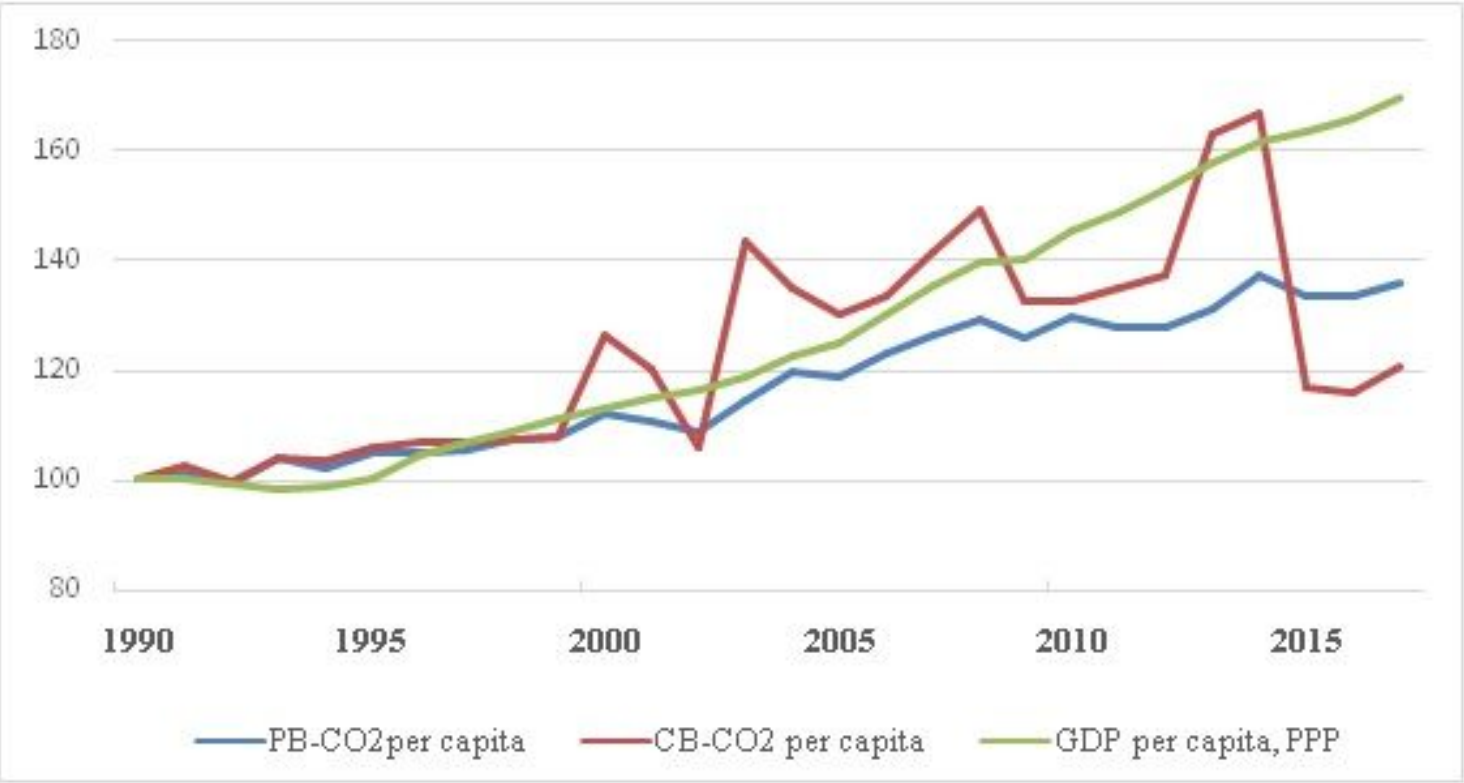

Figure 1

Per capita CO2 emissions and GDP per capita, PPP $(1990=100)$ 